\title{
Induction of ovarian growth in Aegla platensis (Crustacea, Aeglidae) by means of neuroregulators incorporated to food
}

\author{
Alejandra V. Cahansky ${ }^{1}$, Bibiana Kaiser Dutra ${ }^{2}$, Daniela da Silva Castiglioni ${ }^{3}$, Guendalina \\ Turcato Oliveira ${ }^{2}$, Georgina Bond Buckup ${ }^{3}$ \& Enrique M. Rodríguez ${ }^{1}$ \\ 1. Depto. de Biodiversidad y Biología Experimental, FCEyN, Universidad de Buenos Aires. Ciudad Universitaria, Pab. \\ II, C1428EHA Buenos Aires, Argentina; enrique@bg.fcen.uba.ar \\ 2. Depto. de Fisiologia, Faculdade de Biociências, PUCRS, Av. Ipiranga, 6681/Pd.12A-CEP: 90619-900. Porto Alegre, \\ Brazil. \\ 3. Depto. of Zoologia, Instituto de Biociências, UFRGS, Av. Bento Goncalves 9500, Predio 43435, Sala 217- CEP: \\ 91501-970, Porto Alegre, RS, Brazil.
}

\section{Received 19-III-2007. Corrected 30-VI-2008. Accepted 31-VII-2008.}

\begin{abstract}
The freshwater crab Aegla platensis was used as a model to induce ovarian growth by adding different neuroregulators to a pellet food formulation. Added compounds were the dopaminergic inhibitor spiperone or the enkephalinergic inhibitor naloxone, both of them at a dose of $10^{-8} \mathrm{~mol} / \mathrm{animal}$. Animals were fed on the enriched pellets twice a week. After $7 \mathrm{wk}$, the gonadosomatic index (GI) was calculated as (gonad fresh weight / body fresh weight) x 100. GI significantly increased only for those females fed on spiperone pellets, compared to a control group receiving pellets with no compound added. During the assayed period, spiperone would be reverting the arrest exerted by dopamine on the neuroendocrine stimulation of ovarian growth. On the other hand, for both spiperone and naloxone a higher GI was correlated to a higher lipid content of both gonads and/or hepatopancreas, suggesting an increased energetic demand in accordance with an active investment in reproduction. Rev. Biol. Trop. 56 (3): 1201-1207. Epub 2008 September 30.
\end{abstract}

Key words: anomuran crabs, reproduction, ovarian growth, naloxone, spiperone.

Several studies on the neuroendocrine control of crustacean reproduction have been developed since ten years ago, both concerning hormones and neuroregulators (Fingerman 1997, Wainwright et al. 2001). As instance, the stimulating effect of serotonin on the secretion of the gonad-stimulating hormone (GSH) from brain and thoracic ganglia has been reported. Moreover, serotonin could act either as neurotransmitters or neurohormone, and its effect on GSH can be antagonized by other neurotransmitter, dopamine (Fingerman 1997). On the other hand, endogenous dopamine showed to have an in vitro stimulatory effect on the secretion of the gonad-inhibiting hormone (GIH) by the eyestalks of the crab Chasmagnathus granulata, such effect being abolished by the addition to the incubation medium of the dopaminergic antagonist spiperone (Zapata et al. 2003). Hence, the administration of this antagonist could be a way to stimulate reproduction in crustaceans. In fact, injection of spiperone to the crayfish Procambarus clarlii produced stimulatory effects on the reproductive performance of both sexes, i.e., an induction of testicular maturation (Sarojini et al. 1995), as well as a stimulation of ovarian growth (Rodriguez et al. 2002). In the crayfish Cherax quadricarinatus, the administration of spiperone stimulated the ovarian growth (Cahansky et al. 2002), and subsequently produced an augmented percentage of spawning females (Cahansky et al. 2003). In penaeoid shrimps (Litopenaeus vannamei and L. stylirsotris), it has also been 
demonstrated that the combined injection of serotonin and spiperone induces ovarian maturation and spawning at rates similar to those caused by eyestalk ablation (Alfaro et al. 2004). Among the neurotransmitters involved in crustacean reproduction, endogenous opioids such as metenkephaline and leuenkephaline have been also reported (Nagabhushanam et al. 1995, Fingerman et al. 1991, Fingerman et al. 1985). Inhibitory effects of these opioids on ovarian growth have been observed, both in the fiddler crab Uca pugilator (Sarojini et al. 1995) and in the crayfish P. clarkii (Sarojini et al. 1996, Sarojini et al. 1997). As mentioned for spiperone, endogenous opioids are probably inhibiting GSH secretion, as well as stimulating GIH secretion. Naloxone, an antagonist of enkephalinergic receptors, has been able to stimulate the ovarian growth of both mentioned species (Sarojini et al. 1995, Sarojini et al. 1997).

Lipids constitute the main energetic reserve of marine invertebrates. Several studies have showed that during periods of high energetic requirement, such as somatic growth, molting or reproduction (ovarian growth, spawning), a high mobilization of lipids takes place, mainly from the hepatopancreas (Kucharski et al. 1991). The high lipid concentration observed in this organ is likely related to the absence of a real adipose tissue in crustaceans. Both hepatopancreas and muscle are considered the main sites for the storage of lipids and also glycogen as reserve substrates (Kucharski et al. 1991).

Aegla platensis Schmitt, 1942 (Crustacea, Decapoda, Aeglidae), is a freshwater species that has a broad distribution in South America, as also have other species of the same genus (Bueno et al. 2000). South American aeglids usually fed on insect larvae and they are relevant items of the diet of fish and birds. The reproductive period of $A$. platensis extents throughout the year, although a lower percentage of ovigerous females can be observed in November and December (Bueno et al. 2000). Since a few years ago, this species has been taken as a model for several physiological studies, due to its cosmopolitan distribution and very good adaptation to laboratory conditions.

This study was aimed at evaluating, by means of in vivo assays, the stimulatory effect of both spiperone and naloxone on the ovarian growth, when they are administered by food to A. platensis. Besides, levels of energetic reserves have been measured in order to correlate their values with the degree of ovarian growth.

\section{MATERIALS AND METHODS}

Adult females of $A$. platensis (Crustacea, Decapoda, Aeglidae), with an average weight of $1.18 \pm 0.10 \mathrm{~g}$, were collected during July 2004 at the Arroio do Mineiro, Rio Grande do Sul, Brazil (2930'02”S, 5046’ 50” W). Animals were carried to the laboratory (UFRGS, Brazil); at the beginning of the experiment (August 12), a sample of 8 females were randomly selected and sacrificed, to serve as the initial control for evaluating the degree of ovarian growth, according to the methodology stated below.

Throughout the experiment, photoperiod and temperature were maintained at 14:10 (L:D) and $15 \pm 1^{\circ} \mathrm{C}$, respectively. Glass aquaria of 9-L capacity were employed, filled with $5 \mathrm{~L}$ of dechlorinated freshwater $(\mathrm{pH}$ : $6,9 \pm 0,2$ ) and provided with little stones and appropriate refuges. A constant aeration was also provided. Three females were randomly assigned to each aquarium and three aquaria were assigned to each of the following experimental groups $(n=9)$ :

$\mathrm{CC}$ (concurrent control): animals fed on control pellets (only vehicle added).

SP: animals fed on pellets enriched with the dopaminegic antagonist spiperone.

NX: animals fed on pellets enriched with the enkephalinergic antagonist naloxone.

All drugs were purchased from Sigma Chemical Co. (St. Louis, Mo). After dissolving them in distilled water (also adding a few drops of acetic acid in the case of spiperone), the antagonists used were mixed with formulated 
diets, consisting in two types of pellet food for fish (TetraPond ${ }^{\circledR}$ and TetraDiskus ${ }^{\circledR}$, blended in a $1: 1 \mathrm{w} / \mathrm{w}$ proportion). The resulting mix was repelletized and dried, to finally obtain pellets of high consistency, each one having a concentration of $10^{-8} \mathrm{~mol}$ of either spiperone or naloxone. Control pellets were prepared with the same methodology as above, but only with the addition of the vehicle (distilled water and acetic acid).

Pellets (both control and enriched with the antagonists) were administered twice a week and at the evening, in accordance with the alimentary habits of the studied species (Bueno et al. 2004). Only one pellet was given to each female in each feeding session, in order to assure a dose of $10^{-8} \mathrm{~mol} / \mathrm{animal}$. This dose was selected according to previous studies made on other crustaceans (Rodriguez et al. 2002, Cahansky et al. 2002). In the same session, as well as in every other day of the week, feeding was complemented with a ration of TetraDiskus ${ }^{\circledR}$ (43\% protein), ad libitum.

All the aquaria were daily inspected in order to detect molts or eventually dead animals that were immediately withdrawn. After 7 wk of experiment, all females were weighed in analytical balance (precision $\pm 0.001 \mathrm{~g}$ ) and a sample of hemolymph was taken from the coxal articulation of walking legs, by means of $1-\mathrm{mL}$ syringe provided with a $27 \mathrm{G}$ needle; potassium oxalate $(10 \%)$ was used as anticoagulant. Hemolymph samples were then transferred to 1-mL Eppendorf tubes and freezed at $-20{ }^{\circ} \mathrm{C}$ until processing as indicated below. Finally, animals were cold anesthetized and their ovaries were quickly dissected and weighed $( \pm$ $0.001 \mathrm{~g}$ ). The gonadosomatic index (GI) was estimated as (gonad fresh weight / body fresh weight) x 100. After weighing, ovaries and also hepatopancreas (previously weighed) were preserved at $-20{ }^{\circ} \mathrm{C}$ for the posterior determination of cholesterol and lipids.

Glucose levels were determined in hemolymph samples by the glucose oxidase method (Labtest kit), while total proteins were measured by the method of Lowry et al. (1951), using bovine albumin as standard. Besides, lipids and cholesterol were extracted from hemolymph following the procedure of Folch et al (1957). Lipids were quantified through the sulfosfovaline method, while cholesterol by means of an enzymatic kit (Labtest). The same methodology was used for determining lipid and cholesterol levels in gonads and hepatopancreas.

A one-way ANOVA, followed by planned comparisons, was used for comparing the experimental groups, for each of the analyzed variables. A confidence level of $95 \%$ was considered in all cases.

\section{RESULTS}

Survival of animals during the assay ranged from $56 \%$ (control and naloxone) to $100 \%$ (spiperone), as shown by Fig. 1. GI values yielded by each experimental group are also shown in Fig. 1, together with the results of the statistical comparisons made. Only the SP group showed a significant (ANOVA, $\mathrm{p}<0.05$ ) higher GI than both the initial and concurrent control groups. Although a high GI mean value was also observed in the NX group, a relative high data dispersion could have masked the existence of significant differences in this later group with respect to the control groups (see Fig. 1).

Table 1 shows the results of the biochemical determinations of energetic reserves. Naloxone produced a significant (ANOVA, $\mathrm{p}<0.05$ ) higher increment of lipids in both gonads and hepatopancreas, while spiperone only produced a significant (ANOVA, $\mathrm{p}<0.05$ ) increment of lipid content in hepatopancreas. Cholesterol content in both gonads and hepatopancreas significantly (ANOVA, $\mathrm{p}<0.05$ ) decreased by effect of naloxone.

\section{DISCUSSION}

The significant biological effects observed in this study with both spiperone and naloxone incorporated to pellet food, clearly showed that both neuroregulators were able to be taken 


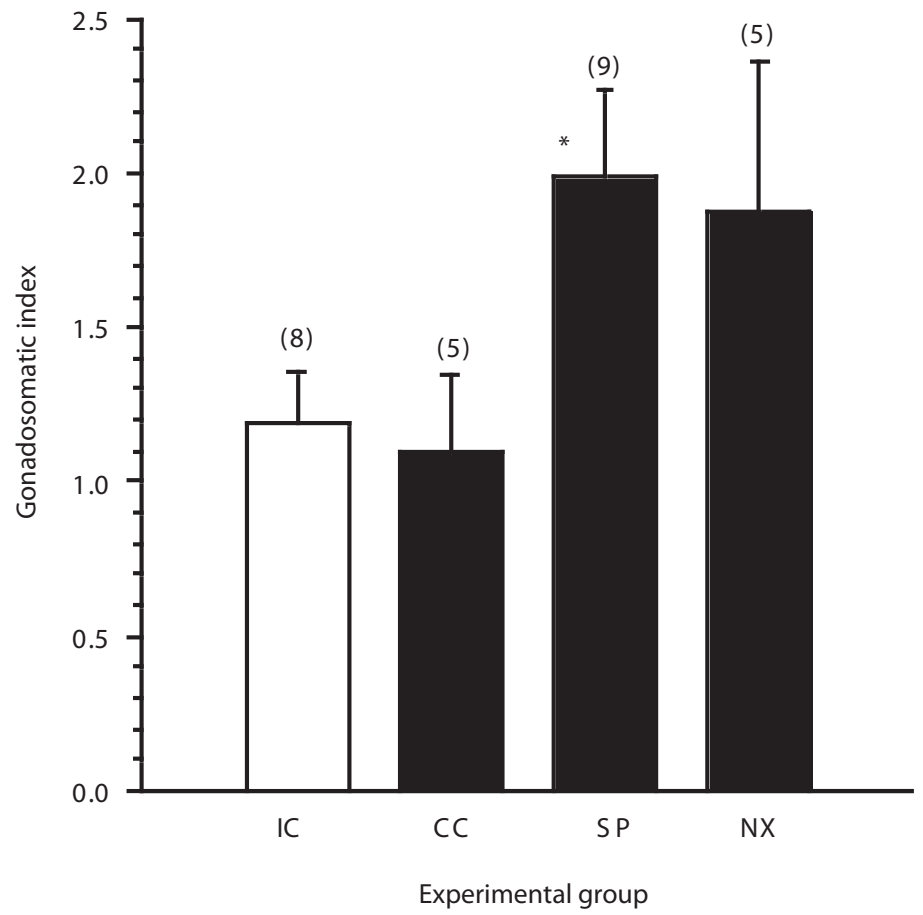

Fig. 1. Mean gonadosomatic index ( \pm standard error) at the end of the 7-wk experiment. Number of animals is indicated between brackets. Asterisk indicates significant $(p<0.05)$ differences with respect to the concurrent control group $(C C)$. IC: initial control group. SP and NX: groups treated with spiperone and naloxone, respectively.

TABLE 1

Mean values ( \pm standard error) of the energetic reserves measured in different tissues of A. platensis at the end of the 7-wk experiment

\begin{tabular}{llrrr} 
Tissue & Substrate & \multicolumn{1}{c}{ CC } & \multicolumn{1}{c}{ SP } & NX \\
& Glucose & $7.57 \pm 0.51$ & $7.43 \pm 0.85$ & $10.59 \pm 1.05$ \\
Hemolymph & Proteins & $12.05 \pm 0.59$ & $11.01 \pm 0.83$ & $8.53 \pm 0.60$ \\
& Lipids & $68.20 \pm 2.40$ & $57.64 \pm 4.49$ & $72.02 \pm 3.03$ \\
& Cholesterol & $13.45 \pm 1.52$ & $9.35 \pm 1.45$ & $7.14 \pm 1.78$ \\
Gonads & Lipids & $10.81 \pm 0.25$ & $16.99 \pm 1.16$ & $75.55 \pm 4.65^{*}$ \\
& Cholesterol & $4.20 \pm 0.90$ & $2.81 \pm 0.67$ & $1.78 \pm 0.41^{*}$ \\
Hepatopancreas & Lipids & $2.93 \pm 0.15$ & $5.97 \pm 0.34 *$ & $7.82 \pm 0.27^{*}$ \\
& Cholesterol & $1.36 \pm 0.26$ & $1.03 \pm 0.17$ & $0.57 \pm 0.19^{*}$
\end{tabular}

All values are expressed in $\mathrm{mg} / \mathrm{g}$. Number of animals is indicated in Fig. 1. Asterisks indicate significant $(p<0.05)$ differences with respect to the concurrent control group (CC). SP and NX: groups treated with spiperone and naloxone, respectively. 
up by animals through the digestive tract. Moreover, the results obtained on A. platensis are validating similar results previously obtained with spiperone on the crab C. granulata (Zapata et al. 2003), the crayfish P. clarkii (Cahansky et al. 2002, Cahansky et al. 2003) and the marine shrimp Litopenaeus (Alfaro et al., 2004), as well as proposing naloxone as another stimulating compound of ovarian growth that could be effectively administered to crustaceans by food. This way of administration undoubtedly constitutes a very useful tool for the culture of crustacean species of high commercial value.

Storage and mobilization of energetic reserves take place during the period of reproductive activity of crustacean females, in order to support the oocyte growing and subsequent spawning (Kucharski et al. 1991). In the current study, a clear correlation between the increment of lipid concentration in hepatopancreas and the increase of gonadosomatic index was verified in the experimental group treated with spiperone. On the other hand, a significant increment of lipids, both in hepatopancreas and gonads, was produced by the administration of naloxone.

During the process known as secondary or exogenous vitellogenesis, a significantly increment of oocyte size occurred, mainly caused by the incorporation of vitellogenin from hemolymph (Adiyodi et al. 1983). The GIH was reported to inhibit the uptake of vitellogenin by oocytes, and probably also to inhibit the synthesis of vitellogenin in extraoocytic sites (Charniaux Cotton 1985). A possible function of dopamine, as endogenous neurotransmitter, stimulating the secretion of GIH by the sinus gland in the eyestalks has been proposed (Fingerman 1997). Therefore, the increased oocyte growing caused by spiperone in the current study, with respect to the concurrent control, has been probable due to the suppression of the dopaminergic stimulation on GIH secretion. A similar consideration is valid for naloxone, although its significant effect on gonadosomatic index needs to be validated on a higher number of animals.
The assayed neuroregulators, i.e., spiperone and naloxone, could be also antagonizing the inhibitory effect of dopamine and opioids, respectively, on the secretion of GSH from brain and thoracic ganglia. Nevertheless, this hormone has not been yet isolated and purified in any crustacean species. According to De Kleijn and Van Herp (1998), this hormonal factor could be an isoform of the crustacean hyperglycemic hormone (CHH). This hormone, belonging to the same family of hormones that includes GIH (Keller 1992), has been classically described as secreted by the eyestalks, but further studies have shown that several isoforms of $\mathrm{CHH}$ are probably secreted from other parts of the nerve system, such as the ventral nerve chain (Charniaux Cotton 1985, FanjulMoles 2006). Several metabolic events, like glycemia increase and mobilization of carbohydrates in several tissues have been reported as the main effects of CHH (Fanjul-Moles 2006, Santos et al. 1993).

Both spiperone and naloxone produced a marked hyperglycemia in P. clarkia, after 60 min of being injected (Sarojini et al. 1995). According to these authors, enkephalinergic neurons would directly innervate the neurosecretory cells of $\mathrm{CHH}$ in the eyestalks, while the dopaminergic neurons would in turn innervate the enkephalinergic ones. Therefore, a stronger effect of naloxone on glycemia increasing is expected, compared to spiperone. In fact, animals fed during the current study on pellets enriched with naloxone showed values of glycemia higher than the ones of the other experimental groups.

Assuming that any isoform of $\mathrm{CHH}$ could stimulate ovarian growing (Charniaux Cotton 1985), increased hemolymphatic titers of this hormone, secreted from either eyestalks or other neurosecretory centers, could explain the increase of lipids in the ovary, as constitutive compounds of the vitellogenin taken by oocytes. Vitellogenin accumulation in the ovary could also be regulated by other hormones that stimulate ovarian growing, such as methyl farnesoate and steroids (Rodriguez et al. 2002a b). The possible influence of dopamine 
or enkephalins on the secretion of such other hormones has not been elucidated up today.

Concerning the accumulation of lipids in the hepatopancreas, no evidences have been provided about the possible mediation of $\mathrm{CHH}$ on that anabolic process. Although methyl farnesoate was able to stimulate the protein synthesis in the hepatopancreas of some species of crustaceans (Homola et al. 1997), no evidences exist on its possible function on lipid metabolism. As for the storage of carbohydrate, a stimulating effect of mammalian insulin on the synthesis of carbohydrates has been reported in crabs (Kucharski et al. 1999). The existence in crustaceans of endogenous insulin-like peptides could be an interesting hormonal pathway to stimulate the accumulation of energetic reserves. If so, its neuroendocrine control and its relationship with reproductive hormones would remain to be elucidated.

\section{ACKNOWLEDGEMENTS}

The current study has been supported by the binational (Argentina-Brazil) program CAPES-SECYT (project 050/03), AVC fellowship (Brazil) and ANPCyT-PICT20707 (Argentina).

\section{RESUMEN}

Se utilizó al anomuro de agua dulce Aegla platensis como modelo para inducir el crecimiento ovárico mediante el agregado de diferentes neuroreguladores a una formulación de alimento pelleteado. Los compuestos agregados fueron el inhibidor dopaminergico spiperona ó el inhibidor encefalinérgico naloxone, ambos a una dosis de $10^{-8}$ moles/animal. Los animales fueron alimentados dos veces a la semana con pellets enriquecidos con alguno de los neuroreguladores. Luego de 7 semanas, se calculó el índice gonadomático (IG) como (peso gonadal fresco/ peso corporal fresco) x 100. El IG mostró un incremento significativamente sólo en aquellas hembras alimentadas con pellets enriquecidos con spiperona, en comparación con un grupo control que recibió pellets sin agregado alguno. Durante el período ensayado, la spiperona estaría revirtiendo el arresto ejercido por la dopamina sobre la estimulación neuroendocrina del crecimiento ovárico. Por otro lado, para ambos grupos experimentales (spiperona y naloxone), un mayor valor de IG estuvo correlacionado a un mayor incremento del contenido de lípidos tanto en gonadas como en hepatopáncreas, sugiriendo una demanda energética incrementada en relación con una activa inversión en reproducción

Palabras clave: anomuros, reproducción, crecimiento ovárico, naloxone, spiperona

\section{REFERENCES}

Alfaro, J., G. Zúñiga \& J. Komen. 2004. Induction of ovarian maturation and spawning by combined treatment of serotonin and a dopamine antagonist, spiperone in Litopenaeus stylirostris. Aquaculture 236: 511-522

Adiyodi, R.G. \& T. Subramonian. 1983. Reproductive biology of invertebrates. Oogenesis, oviposition and oosorption, p. 443-495. In KG R.G. Adiyodi \& R.G. Adiyodi (eds). Arthropoda-Crustacea. John Wiley, New York, USA.

Bueno, A.A.P. \& G. Bond-Buckup. 2004. Natural diet of Aegla platensis Schmitt and Aegla ligulata BondBuckup \& Buckup (Crustacea, Decapoda, Aeglidae) from Brazil. Acta Limnol. Bras.16: 115-127.

Bueno, A.A.P. \& G. Bond-Buckup. 2003. Dinamica populacional de Aegla platensis Schmitt (Crustacea, Decapoda, Aeglidae). Rev. Bras. Zool. 17: 43-49.

Charniaux Cotton, H. 1985. Vitellogenesis and its control in malacostracan Crustacea. Am. Zool. 25: 197-206.

De Kleijn, D.P.V. \& F. Van Herp. 1998. Involvement of the hyperglycemic neurohormone family in the control of reproduction in decapod crustaceans. Invertebr. Reprod. Dev. 33: 263-272.

Fanjul-Moles, M.L. 2006. Biochemical and functional aspects of crustacean hyperglycemic hormone in decapod crustaceans: Review and update. Comp. Biochem. Physiol. 142C: 390-400.

Fingerman, M. \& G. Kulkarni. 1991. Biologically active peptides of crustacean nervous system: their roles as neurohormones, neurotransmitters and neuromodulators, p. 237-242. In M. Thompson, R. Sarojini \& R. Nagabhushanam (eds). Bioactive compounds from marine organism. Oxford \& IBH Publishing Co., New Delhi, India..

Fingerman, M. 1997. Roles of neurotransmitters in regulating reproductive hormone release and gonadal maturation in decapod crustaceans. Invertebr. Reprod. Dev. 31: 47-54.

Fingerman, M., M. Hunumante, G. Kulkarni, R. Ikeda \& L. Vacca. 1985. Localization of substance P-like, 
leucine-enkephalin-like, methionine- enkephalinlike, and FMRFamide-like inmunoreactivity in the eyestalk of the fiddler crab, Uca pugilator. Cell. Tissue Res. 241: 473-477.

Folch, J., M. Lees \& H.S. Stanley. 1957. A simple method for isolation and purification of total lipids from animal tissues. J. Biol. Chem. 226: 497-503.

Homola, E. \& E.S. Chang. 1997. Methyl farnesoate: crustaceans juvenile hormone in search of function. Comp. Biochem. Physiol. 117B: 347-356.

Keller, R. 1992. Crustacean neuropeptides: structure, functions and comparative aspects. Experientia 48: 439448.

Kucharski, L.C., E. Capp, A.L. Chitt, M. Trapp \& R.S.M. Da Silva. 1999. Marques M. Insulin signaling: tyrosine kinase activity in the crab Chasmagnathus granulata gills. J. Exp. Zool. 283: 91-94.

Kucharski, L.C. \& R.S.M. Da Silva. 1991. Seasonal variation in the energy metabolism in an estuarine crab, Chasmagnathus granulata (Dana, 1851). Comp. Biochem. Physiol. 100A: 599-602.

Lowry, O.H., N.J. Rosenbrough, A.L. Fau \& R.J. Randal. 1951. Protein measurements with the folin phenol reagent. J. Biol. Chem. 193: 265-275.

Nagabhushanam, R., R. Sarojini, P. Reddy, M. Devi \& M. Fingerman. 1995. Opioid peptides in invertebrates: Localization, distribution and possible functional roles. Curr. Sci. India 69: 659-671.

Rodríguez, E.M., L.S. López Greco, D.A. Medesani, H. Laufer \& M. Fingerman. 2002a. Effect of methyl farnesoate, alone and in combination with other hormones, on ovarian growth of the red swamp crayfish, Procambarus clarkii, during vitellogenesis. Gen. Comp. Endocrinol. 125: 34-40.

Rodríguez, E.M., D.A. Medesani, L.S. López Greco \& M. Fingerman. 2002b. Effects of some steroids and other compounds on ovarian growth of the red swamp crayfish, Procambarus clarkii, during early vitellogenesis. J. Exp. Zool. 292: 82-87.

Santos, E.A. \& R. Keller. 1993. Crustacean hyperglycemic hormone $(\mathrm{CHH})$ and the regulation of carbohydrate metabolism: current perspectives. Comp. Biochem. Physiol. 106A: 405-411.

Sarojini, R., R. Nagabhushanam \& M. Fingerman. 1996. In vivo assessment of opiod agonist and antagonist on ovarian maturation in the red swamp crayfish, Procambarus clarkii. Comp. Biochem. Physiol. 115C: 149-153.

Sarojini, R., R. Nagabhushanam \& M. Fingerman. 1997. An in vitro study of the inhibitory action of methionine enkephaline on ovarian maturation in the red swamp crayfish, Procambarus clarkii. Comp. Biochem. Physiol. 117C: 207-210.

Sarojini, R., R. Nagabhushanam \& M. Fingerman. 1995. Dopaminergic and enkephalinergic involvement in the regulation of blood glucose in the red swamp crayfish, Procambarus clarkii. Gen. Comp. Endocrinol. 97: 160-170.

Sarojini, R., R. Nagabhushanam \& M. Fingerman. 1995. Evidence for opiod involvement in the regulation of ovarian maturation of the fiddler crab, Uca pugilator. Comp. Biochem. Physiol. 111A: 279-282.

Sarojini, R., R. Nagabhushanam \& M. Fingerman. 1995. In vivo effects of dopamine and dopaminergic antagonists on testicular maturation in the red swamp crayfish, Procambarus clarkii. Biol. Bull. 189: 340-346.

Wainwright, G. \& H. Rees. 2001. Hormonal regulation of reproductive development in crustaceans, p. 71-84. In D. Atkinson \& M. Thorndyke (eds). Environment and Animal Development. Scientific Publishers Limited, Oxford, England.

Zapata, V., L.S. López Greco, D.A. Medesani \& E.M. Rodríguez. 2003. Ovarian growth in the crab Chasmagnathus granulata, induced by hormones and neuroregulators throughout the year. In vivo and in vitro studies. Aquaculture 224: 339-352.

\section{INTERNET REFERENCES}

Cahansky, A., L.S. López Greco \& E.M. Rodríguez. 2002. Incremento de la producción de hembras ovígeras de la langosta de Agua Dulce (Cherax quadricarinatus) durante el periodo reproductivo, mediante la administración de hormonas y neuroreguladores. Available at http://www.revistaaquatic. com/CIVA2003/. Downloaded 29 March 2008.

Cahansky, A., L.S. López Greco \& E.M. Rodríguez. 2002. Inducción de crecimiento ovárico en Cherax quadricarinatus, mediante hormonas y neuroreguladores incorporados en el alimento. Available at http:// www.revistaaquatic.com/CIVA2002/. Downloaded 29 March 2008. 
